D

'Dept of Pharmacology and Toxicology, Maastricht University, Maastricht, The Netherlands. ${ }^{2}$ Respiratory and Sleep Diagnostics, Midland Regional Hospital, Mullingar, Ireland. ${ }^{3}$ Dept of Pneumonology, School of Medicine in Katowice, Medical University of Silesia, Katowice, Poland. ${ }_{4}^{4}$ Institute of Occupational Medicine and Environmental Health, Sosnowiec, Poland.

\title{
Opportunities for ERS junior members in 2016
}

\section{Juniors' voice}

The Junior Members Committee (JMC) is happy to announce another new year of opportunities for European Respiratory Society (ERS) junior members. ERS has significantly evolved and so has the JMC. At the Amsterdam International Congress, new JMC members were elected during assembly meetings. The elections took place in assemblies 1, 6, 8, 9 and 10. Detailed information about new member's activities, along with a contact list, is summarised in table 1. Please use table 1 to guide you on how to get directly involved with junior dedicated ERS activities and your JMC representative.

The new members are warmly welcomed to the committee and are already included in some of the major JMC activities. Aside election of the new JMC members, a new JMC Chair was elected. Agnes Boots was chosen to represent the JMC the year 2015/2016. In the following paragraph, Agnes will give us an overview of her vision and plans for the time of her chairmanship.

"During the 2 years that I have been involved in the JMC, I have experienced and witnessed how much we can do with and for the junior members of the ERS. Just by looking at the large increase in the numbers of juniors involved in chairing sessions during the International Congress in Amsterdam (due to the new JMC initiative of providing all assemblies with a juniors' competence list), we can already conclude that we are successful in promoting the interests of the junior members. Moreover, the very well attended JMC session "ERS and You" during last year's Congress and the even more crowded junior networking event afterwards, showed once more how needed and welcomed our committee is by the junior members of the Society. Indeed, by speaking to many of the (new) juniors during the networking event, it became very clear to me how they appreciate our work and depend on our knowledge, network and activities to become actively involved in the ERS. I am excited by the new ideas for the JMC suggested by junior members and I am very happy to say that some of these have already been initiated with the help of enthusiastic juniors outside of the JMC. As the new chair, I want the JMC to continue communicating directly with the junior members, and incorporating their ideas and needs into our work in order to ensure a maximal interaction with the ERS. By enhancing the commitment of all juniors as well as each member of the committee, I believe it will be possible to stay a strong and
Cite as: Boots A, Flood E, Skoczynski S. Juniors' voice: Opportunities for ERS junior members in 2016. Breathe 2016; 12: 69-71. 
Table 1 Contact details and roles of the members of the JMC

\begin{tabular}{|c|c|c|c|c|}
\hline Name (country) & Assembly & Profession & Other JMC duties & E-mail \\
\hline $\begin{array}{l}\text { Nicolas Kahn } \\
\text { (Germany) }\end{array}$ & 1 & $\begin{array}{l}\text { Clinical fellow in } \\
\text { respiratory medicine; } \\
\text { physician student }\end{array}$ & $\begin{array}{l}\text { Representative to the Science } \\
\text { Council }\end{array}$ & nicolas.kahn@web.de \\
\hline $\begin{array}{l}\text { Szymon Skoczynski } \\
\text { (Poland) }\end{array}$ & 2 & Pulmonologist & $\begin{array}{l}\text { JMC-Breathe collaboration } \\
\text { (Juniors' voice) } \\
\text { Representative on HERMES: Adult } \\
\text { and Respiratory Critical Care } \\
\text { Representative to the Adult Training } \\
\text { Centre Accreditation Committee }\end{array}$ & simon.mds@poczt.fm \\
\hline $\begin{array}{l}\text { Agnes Boots } \\
\text { JMC Chair } \\
\text { (The Netherlands) }\end{array}$ & 3 & $\begin{array}{l}\text { Assistant professor in } \\
\text { respiratory toxicology }\end{array}$ & $\begin{array}{l}\text { JMC Chair } \\
\text { International congresses } \\
\text { Fellowships - Representative to the } \\
\text { Education Council }\end{array}$ & a.boots@maastrichtuniversity.nl \\
\hline $\begin{array}{l}\text { Hanneke van Helvott } \\
\text { (The Netherlands) }\end{array}$ & 4 & Medical physiologist & $\begin{array}{l}\text { Mass emails, surveys for the JMC, } \\
\text { Facebook, Twitter, etc. }\end{array}$ & Hanneke.vanhelvoort@radboudumc.nl \\
\hline $\begin{array}{l}\text { Ane Aamli } \\
\text { (Norway) }\end{array}$ & 6 & $\begin{array}{l}\text { Medical student and } \\
\text { reseacher }\end{array}$ & $\begin{array}{l}\text { JMC-ELF collaboration ("How to } \\
\text { Sessions") }\end{array}$ & aneaamli@hotmail.com \\
\hline $\begin{array}{l}\text { Daan Caudri } \\
\text { (The Netherlands) }\end{array}$ & 7 & $\begin{array}{l}\text { Paediatrician and clinical } \\
\text { epidemiologist }\end{array}$ & $\begin{array}{l}\text { Representative to the guidelines } \\
\text { committee }\end{array}$ & d.caudri@erasmusmc.nl \\
\hline $\begin{array}{l}\text { Bart Vanaudenaerde } \\
\text { (Belgium) }\end{array}$ & 8 & $\begin{array}{l}\text { Assistant professor in } \\
\text { respiratory medicine }\end{array}$ & & Bart.Vanaudenaerde@med.kuleuven.be \\
\hline $\begin{array}{l}\text { Emma Flood } \\
\text { (Ireland) }\end{array}$ & 9 & $\begin{array}{l}\text { Senior respiratory and } \\
\text { sleep physiologist }\end{array}$ & $\begin{array}{l}\text { JMC-Breathe collaboration } \\
\text { (Junior's voice) }\end{array}$ & emma.flood@hse.ie \\
\hline $\begin{array}{l}\text { Aran Singanayagam } \\
\text { (UK) }\end{array}$ & 10 & $\begin{array}{l}\text { Academic clinical } \\
\text { lecturer in respiratory } \\
\text { medicine }\end{array}$ & $\begin{array}{l}\text { JMC-Breathe collaboration (Hot } \\
\text { Topics from the Assemblies) }\end{array}$ & aransinga@gmail.com \\
\hline
\end{tabular}

HERMES: Harmonising Education in Respiratory Medicine for European Specialists; ELF: European Lung Foundation.

optimally functional committee that represents all junior members of the ERS to the fullest."

The JMC wishes Agnes all the best for her time as the JMC chair.

In the following paragraphs Emma Flood, one of our newly elected JMC members will introduce herself and her planned activities and vision JMC vision in the coming years.

"I have been elected to represent Assembly 9 on the JMC. Assembly 9 is the Allied Respiratory Professionals group encompassing respiratory function technologists/scientists, physiotherapists and nurses. It is increasingly recognised that allied healthcare professionals play an important role in the diagnosis, treatment and care of patients with pulmonary diseases. I hope to play a role in engaging junior members of Assembly 9, and also those within my own country of Ireland, to fully participate in the ERS and its activities. It is a privilege to work with the JMC to promote junior members and I hope to continue the already successful relationship we have with the ERS. As I am new to the role, I urge any junior member of Assembly 9 to get in touch with me so I can be a useful representative to promote our interests and thoughts!

As part of my role on the JMC committee, I have put myself forward to work with Szymon on the Juniors' voice section of Breathe. The JMC have suggested that the newer members work should alongside the current representatives to gain some of their expertise before taking over when representatives on the JMC change.

Juniors' voice is an important section in Breathe. We hope to use Juniors' voice to keep you informed of scientific and clinical information from the ERS International Congress and ERS Lung Science Conference as well as providing information about dedicated JMC activities and opportunities.

I hope to fulfil the role to the best of my ability and look forward to the exciting opportunity of working on the ERS JMC!"

To conclude, we can confirm that the JMC is actively involved in the growing number of ERS activities and ERS bodies. The JMC aims are unchanged and to provide junior representation in the ERS leadership and flagship projects. 
To be even more efficient the JMC needs to be heard, but on top of this, it needs to listen to and correspond with as many juniors as possible. Therefore, we would like to encourage all juniors to contact us with any ideas, concerns, needs and comments you may have, but more importantly, please contact us to become actively involved in the ERS and help out with the diversity of tasks the $J M C$ is currently undertaking. The major routes are presented in table 1 , but please also remember our website (http://juniors.ersnet.org/).

Similar to previous years, we will also be present at the 2016 Lung Science Conference in Estoril, Portugal. This small conference is vital for junior scientists interested in lung diseases as it offers the best possible chance for personal contact with authorities in respiratory science as well as other juniors to discuss science, exchange ideas and build a network. All JMC members will be there to answer any questions and introduce you to ERS faculty members. This opportunity was found very effective in previous years, especially because the size of the meeting makes it possible to interact with all participants.

Finally, we want to underline that we are looking forward to hear from you. After all, you are the future of the Society, so please join our efforts to influence its future development.

\section{Conflict of interest}

None declared. 